\title{
Investigation and Research on Employment Guidance Service based on the Demand of Higher Vocational Graduates
}

\author{
Zhang Wu \\ Guangxi Vocational \& Technical Institute of Industry, Nanning, Guangxi, 530001
}

\begin{abstract}
Scientific employment guidance service system can effectively help the university graduates to accurately grasp their own position, to enhance employability and ability to adapt to the environment has a positive meaning. In this paper, based on the multiple Department of Guangxi Institute of Industry Technology (Department) of the relevant data of graduate employment guidance service demand investigation and analysis, put forward from the optimization of employment guidance course curriculum, strengthen the construction of the Career Guidance Troop and reading service and other aspects to carry out the workplace employment counseling, effectively improve the quality of college students employment guidance services.

KEYWORD: Vocational College; graduates; employment guidance services
\end{abstract}

In recent years, along with the number of graduates of college students in China increased rapidly, the employment problem of college students has become increasingly prominent, vocational college students because of the lack of experience of the workplace, face greater pressure on employment. According to the investigation and statistics of Science Engineering Department of employment guidance of college graduates at present mainly has following several aspects of problems to be solved: the lack of employment market demand oriented necessary; positioning fuzzy; initial and sustained employment required perseverance ability needs to improve; working experience and knowledge is insufficient; employment ability to produce psychological pressure in 5 aspects. Help the students out of the plight of employment will be a long-term and arduous task of school and society. In this paper, through the analysis of the relevant data on employment guidance service demand of graduates of the Guangxi Institute of Industry Technology survey, combined with the employment guidance education experiment in our hospital, to put forward specific methods of employment guidance service for graduates employment guidance.

Author introduction: Zhang $\mathrm{Wu}$ (1966.5-), male, the Han nationality, Guangxi Bobai person, Guangxi Institute of Industry Technology Department of secretary of Party branch of management science, associate professor, research direction: College Students' Ideological and political education and employment.

\section{INVESTIGATION AND ANALYSIS ON THE DEMAND SITUATION OF GRADUATES EMPLOYMENT INFORMATION}

Investigation of the main ways of graduates obtain employment information and employment guidance. Obtain employment guidance information for accurate understanding of the situation of graduates, seven Department of the author on batch College (Department) used a random sample survey of the 2012 session of the 2013 graduates, 1000 students(can choose more than one), the survey data obtained on the graduates obtain employment information and guidance, graduates obtain employment way knowledge are: employment guidance courses, lectures and activities, online query, related consulting book, parents and social relations, the Encyclopedia of knowledge competition, social practice; the number of selection corresponds to obtain employment of the path of knowledge (people) respectively: 720, 180, 680, 550, $240,120,180$; the corresponding proportion (\%) respectively: $72 \%, 18 \%, 68 \%, 55 \%, 24 \%, 12 \%, 32 \%$. In this survey, $72 \%$ of the students said that obtain employment guidance counseling through the employment guidance, more than $55 \%$ of the students said they can query through the network and the press access to obtain employment related information. This investigation shows that through the course of employment guidance, reading channel to obtain employment counseling is one of the most main ways, thus provides the basis and necessity to 
improve graduates employment ability for school through the employment guidance, professional reading service.

In order to understand the changes before and after the graduates in the industry needs, to develop specific methods of employment guidance service in 2012, December and 2013 the author respectively for different professional college graduates and has tried not to try industry graduates do sampling questionnaire survey on workplace employment information needs. The results of the survey are as follows: 1. The investigation object is not the test industry: college graduates of 300 people, the corresponding sampling questionnaire: occupation career planning, information collection and analysis, the employment policy and market information, employment psychological guidance, interview skills, occupation guidance analysis of successful case, entrepreneurial way 7 aspects respectively: $80 \%$, the demand for data $90 \%, 60 \%, 40 \%, 60 \%$, $40 \%, 60 \%$; the investigation object: try industry 100 graduates, corresponding to the sampling questionnaire: occupation career planning, information collection and analysis, the employment policy and market information, employment psychological guidance, interview skills, occupation guidance analysis of successful case, entrepreneurial way 7 aspects demand data are: $60 \%, 60 \%, 60 \%$, $70 \%, 46 \%, 60 \%, 60 \%$.

From the results, not try industry graduates uncertainty on the occupation planning and positioning, need guidance to smooth employment, at the same time, due to lack of experience, cannot effectively on the employment information and analysis. From the survey has been test industry at graduation, because have begun to try industry, facing many problems and setbacks, in urgent need of workplace experience, psychological adjustment advisory, but whether or not the test industry, graduates have great interest and expectation of selfhelp business. The above data in favor of the school according to the effective employment guidance services.

\section{TO EXPLORE THE IMPLEMENTATION WAY OF PROMOTING GRADUATE EMPLOYMENT GUIDANCE SERVICE QUALITY}

Employment guidance service should be run through the student career beginning, students from entrance to graduation, the school must carry out, construction employment and entrepreneurship guidance service system, the formation mechanism and the method of the effective employment guidance.

\subsection{Strengthen the employment guidance service teachers team construction}

\subsubsection{The advance of teacher specialization.}

The establishment of a branch by internal and external experts and scholars, well-known entrepreneurs, outstanding alumni, professional teachers and counselors, composed with professional and professional employment guidance team.

\subsubsection{Promote teachers professional.}

Strengthen the employment guidance staff training, to master the employment comprehensive professional knowledge, and the organization of employment guidance teachers to business credentials post exercise, participation in industry innovation, the accumulation of experience.

\subsection{Construct curriculum system in accordance with the laws of the growth of the students}

Construct curriculum system in accordance with the laws of the growth of students, practice enriches the content of employment guidance course.

\subsubsection{Employment guidance curriculum design}

The author served as college students employment guidance course at the Guangxi Institute of Industry Technology Department of management science, according to the psychological characteristics and needs of different stages of college students and the curriculum design of the employer needs, the teaching content will be divided into three big modules. Employment guidance curriculum design as follows: module 1 --quasi people job oriented (new stage). Focus on the target: training, employment consciousness occupation comprehensive ability (expression, writing, etiquette and so on), the information acquisition ability. Teaching contents: from the perspective of enterprise to certain occupation people, language expression, communication ability training, courseware, workplace etiquette training. Module 2: professional orientation and development (grade two university). On the aim: professional skills ability, career planning ability. Teaching contents: industry research, understand the typical professional and special position, all kinds of professional qualification research skills, career planning. Module 3 - job ability promotion (University of grade three). Focus on the target: the employment of combat capability. Teaching contents: Master resume writing, interview skills, personalized learning method of assault counseling, employment and workplace issues analysis case. 


\subsubsection{Build entrepreneurial education practice platform, emphasizing the entrepreneurial ability cultivation}

A. set up the venture exchange platform. Combined with the relevant departments of the government run "pioneering project big lecture room", "College Students' innovative undertaking quality big lecture room", the organization planning "entrepreneurial sail" series of activities, the analysis of entrepreneurial success experience, to provide business communication platform.

B. set up the venture organization platform. Give full play to the enthusiasm of students self education, self management, self practice, guidance establish students entrepreneurial community, to provide business organization platform, carry out rich and colorful entrepreneurial practice.

C. to build enterprise competition platform. Insist on holding to "start design competition", "science and technology innovation contest", "science and Technology Culture Festival", "the sand table simulation contest" entrepreneurship competition, attract individual entrepreneurial team, students.

D. to build the market operation platform. To encourage outstanding students entrepreneurial team registered company directly to the business sector, with independent Incorporated Company for the operation of the market, directly to the market to the project, to order.

\subsubsection{College Students' psychological courses open workplace, alleviate the employment psychological pressure}

The common psychological problems for graduates in employment, unemployment, encountered in the test industry, through psychological counseling and psychological counseling to help students understand their own objective, do face reality, dare to compete, not afraid of setbacks, develop self regulating self guided habit and ability.

\subsection{Strengthen the construction of network information tracking guidance, guidance for immediate employment}

\subsubsection{Construct and perfect the function of complete information network platform}

Make full use of resources and technological advantages to establish a large amount of information and the information network platform anxious students required close to student groups and organizations, make full use of the employment website propaganda and introduction of graduate school, invisible employment market to establish and perfect the school graduates, efforts to improve the timeliness, employment information and timely availability, so that to help students face the employment.

\subsubsection{The use of modern network tools, provide employment guidance and consultation services of high quality for the employment of graduates}

The use of modern network tool, counselors can any expansion of employment guidance and consultation, the first time to use the network online answer graduates related questions, provide policy, laws and regulations, the employing units and other information, and can practice stage in post graduates to provide psychological, work and life more comprehensive guidance, timely help to solve the practical problems encountered in the process of graduates in employment, eliminate the unstable factors, enhance the stability of employment.

\subsection{On Graduates' employment of reading guidance service utilization of Library Resources}

From 2011, to carry out various forms of Reading Guidance Service Department of management science has taken the lead in the joint library, will obtain employment information from the new start of consciousness, accumulation of workplace employment information, employment psychological ability enhancement good experience through reading, and achieved significant results.

\subsubsection{Workplace employment guidance service of document retrieval}

Academic Libraries in campus network is the network platform, combined with various universities establish a college career employment information and consulting services and information network, propaganda and guidance for workplace employment related information knowledge. The development of university library lecture, graduates of network retrieval aspects of training, let the graduates get more career information.

\subsubsection{To carry out long-term career employment reading guidance service, help students to choose the rational and positioning}

Due to lack of their graduates and social cognition, often cause for employment at a loss and the position of the. Therefore, the library should use its own advantages, to provide comprehensive professional career employment information. For example, rich workplace employment journal collections: the career guidance class, such as "University - the workplace", "Chinese undergraduate obtain employment", "to go abroad and employment", "market information"; workplace experience category, such as "professional" and "Vocational space", "the starting line" workplace; occupational health category, such as "psychological doctor", "Chinese health"; labor security, such as "employment and safeguard", "personnel world" and 
so on, in order to make the students conscious understanding and accumulation about employment information, help students to choose the rational and positioning.

\section{CONCLUSION}

Practice shows that, the science of employment guidance service system can effectively help college graduates to set up correct employment view, can help them learn more job hunting skills and methods, can help them correct understanding and self evaluation. In practical work, in-depth students understand the actual needs of the students, but also to do a good job tracking analysis and survey of graduates of market demand, the scientific analysis of the employment situation, let the students to establish a correct view of employment, early good occupation career planning. These a few years, we optimized the employment guidance courses, strengthen the construction of the employment guidance team and carry out all workplace employment counseling reading service and so on, not only improve the quality of college students employment guidance service, at the same time, the employment rate of students also greatly enhance, university graduates in recent three years the author of the Institute of the employment rate of more than $94 \%$, get good effect.

\section{REFERENCES}

[1] Han Yan. People forum, construction of employment guidance service system of College Students' 2011, (5): $150-151$. 